\title{
Regulation of adipose tissue leptin secretion by $\alpha$-melanocyte-stimulating hormone and agouti-related protein: further evidence of an interaction between leptin and the melanocortin signalling system
}

\author{
N Hoggard, L Hunter, J S Duncan and D V Rayner \\ Energy Balance and Obesity Division, Aberdeen Centre for Energy Regulation and Obesity, Rowett Research Institute, Aberdeen, UK \\ (Requests for offprints should be addressed to N Hoggard, Energy Balance and Obesity Division, Aberdeen Centre for Energy Regulation and \\ Obesity, Rowett Research Institute, Greenburn Road, Bucksburn, Aberdeen AB21 9SB, UK; Email: nh@ rowett.ac.uk)
}

\begin{abstract}
The central role of the melanocortin system in the regulation of energy balance has been studied in great detail. However, the functions of circulating melanocortins and the roles of their peripheral receptors remain to be elucidated. There is increasing evidence of a peripheral action of melanocortins in the regulation of leptin production by adipocytes. Here we investigate the interaction of $\alpha$-melanocyte stimulating hormone $(\alpha-\mathrm{MSH})$ and agouti-related protein (AgRP) in the regulation of leptin secretion from cultured rat adipocytes and examine the changes in circulating $\alpha-\mathrm{MSH}$ and AgRP in lean and obese rodents after hormonal and energetic challenge. Leptin secretion (measured by ELISA) and gene expression (by real-time quantitative PCR) of differentiated rat adipocytes cultured in vitro were inhibited by the administration of $\alpha-\mathrm{MSH}\left(\mathrm{EC}_{50}=0.24 \mathrm{nM}\right)$, and this effect was antagonised by antagonists of the melanocortin receptors MC4R and MC3R (AgRP and SHU9119). The presence of MC4R in rat adipocytes (RT-PCR and restriction digest) supports the involvement of this receptor subtype in this interaction. Leptin administered to ob/ob mice in turn increases the release of $\alpha$-MSH into the circulation, suggesting a possible feedback loop between the site of $\alpha-\mathrm{MSH}$ release and the release of leptin from the adipose tissue. However, the physiological significance of this putative feedback probably depends upon the underlying state of energy balance, since in the fasting state low plasma $\alpha-\mathrm{MSH}$ is paralleled by low plasma leptin.
\end{abstract}

Journal of Molecular Endocrinology (2004) 32, 145-153

\section{Introduction}

Leptin secreted by adipose tissue regulates energy balance principally through its hypothalamic receptors. Although leptin receptors in the hypothalamus are known to interact with pathways involving a number of neuropeptides, neurons originating in the arcuate nucleus that release $\alpha$-melanocyte stimulating hormone $(\alpha-\mathrm{MSH})$ in the paraventricular nucleus form an important part of this system. The melanocortin receptors (MC-Rs) thought to be involved in the energy balance signalling are the MC4R and MC3R. An integral part of this system appears to be another leptin-sensitive pathway releasing agouti-related protein $(\mathrm{AgRP})$, an MC4/3R antagonist. Leptin thus stimulates $\alpha$-MSH and inhibits AgRP in a coordinated manner to regulate food intake. For this reason much attention has been focused on the role of the melanocortin system in obesity (see Ahima et al. 2000, MacNeil et al. 2002, Zimanyi \& Pelleymounter 2003).

Melanocortin peptides are generated from a common precursor glycoprotein, proopiomelanocortin (POMC), by post-translational processing. The POMC gene is expressed at high levels in the arcuate nucleus of the hypothalamus. It is also expressed in the anterior and intermediate lobes of the pituitary, and at lower levels in a wide variety of mammalian peripheral tissues. $\mathrm{MSH}_{\mathrm{s}}$ are now recognised to have a variety of physiological functions, reflecting the wide distribution of their 
corresponding MC-Rs (Zimanyi \& Pelleymounter 2003). Five subtypes of MC-Rs have been identified (MC1-5R) with discrete pharmacological properties and tissue distribution, including several subtypes present in adipose tissue (MC1R, MC2R, MC4R and MC5R) (Boston \& Cone 1996, Chagnon et al. 1997). Two endogenous antagonists of MC-Rs have been identified, agouti and AgRP (Zimanyi \& Pelleymounter 2003). AgRP is also present in the systemic circulation (Li et al. 2000). The function of circulating AgRP along with the peripheral roles of melanocortins and MC-Rs remain to be elucidated. $\alpha-\mathrm{MSH}$ has been shown to interact with several peripheral organ systems. It is a potent lipolytic agent in a number of species. This was first identified over 25 years ago in rabbits (Kastin et al. 1975), and recently similarly potent lipolytic activity has been shown in rodents, providing support for a role of $\alpha-\mathrm{MSH}$ in the integration of peripheral metabolism with central appetite regulation (Forbes et al. 2001). $\alpha$-MSH has been reported to regulate insulin secretion, inhibit the effects of cytokines and apoptosis, stimulate corticosterone release, and to have a role in thermogenesis (Vinson et al. 1983, Shimizu et al. 1995, Rajora et al. 1997, Forbes et al. 2001, Jo et al. 2001). In addition there is increasing evidence for a peripheral action of melanocortins in the regulation of leptin production by adipocytes (Hoggard et al. 2001, Norman et al. 2003).

In this paper we investigate the interaction of $\alpha-\mathrm{MSH}$ and AgRP in the regulation of leptin secretion from cultured rat adipocytes and examine the changes in circulating $\alpha-\mathrm{MSH}$ and AgRP in relation to energy balance and leptin signalling in both lean and obese rodents. This study, part of which has been published in abstract form (Hoggard et al. 2001), extends the recent reports of an interaction between leptin and melanocortins in murine adipocyte culture (Norman et al. 2003).

\section{Materials and methods}

\section{Animals}

Lean (+/?) and obese $(o b / o b)$ Aston mice (11 weeks), Hooded Lister rats (14 days), and lean $(+/$ ?) and obese Zucker $(f a / f a)$ rats (14 weeks) were all drawn from colonies maintained at the Rowett Research Institute. Food (Biosure; Special Diets
Services, Witham, Essex, UK) and water were available freely unless stated. All animals were killed by cervical dislocation in the middle of the light phase. To examine the effects of food deprivation, lean (+/?) Aston mice were fasted for $24 \mathrm{~h}$. To test the effect of leptin challenge, obese $(o b / o b)$ Aston mice were injected i.p. with either leptin $(1.7 \mathrm{mg} / \mathrm{kg}$ body weight) or saline. Animals were killed by cervical dislocation $1 \mathrm{~h}$ after injection. Tissues were dissected and frozen immediately in liquid nitrogen prior to transfer to $-80{ }^{\circ} \mathrm{C}$ where they were stored until extraction of RNA. All procedures were licensed under the UK Animals (Scientific Procedures) Act of 1986 and received ethical approval from the Rowett Research Institute's Ethical Review Committee.

\section{Hormones}

$\alpha-\mathrm{MSH}$ (Sigma; M4135), [Nle $\left.{ }^{4}, \mathrm{D}-\mathrm{Phe}^{7}\right]-\alpha \mathrm{MSH}$ (Sigma; M8764) and SHU9119 (Sigma; M4603) were purchased from Sigma-Aldrich Company Ltd, Poole, Dorset, UK. AgRP (005-57) was purchased from Phoenix Peptides, Belmont, CA, USA.

\section{Cell culture}

Fibroblastic preadipocytes were isolated from adipose tissue as previously described (Mitchell et al. 1997). The inguinal fat pads from 14-day-old male Hooded Lister rats (eight per group) were removed under sterile conditions. The resultant cell preparation (mainly fibroblastic preadipocytes) was adjusted to a density of $1.5 \times 10^{5}$ cells $/ \mathrm{ml}$ in Medium 199 with $10 \%$ fetal calf serum (Gibco BRL); $1.5 \mathrm{ml}$ volumes were plated onto six-well plates. After 4 days in culture at $37^{\circ} \mathrm{C}$ in an atmosphere of $5 \% \quad \mathrm{CO}_{2}$, differentiation was induced by the addition of medium supplemented with isobutylmethylxanthine $(0.5 \mathrm{mM}$; Sigma), dexamethasone $(0.25 \mathrm{mM}$; Sigma $)$ and insulin (10 mg/ml; CP Pharmaceuticals, Wrexham, UK). After $48 \mathrm{~h}$, the induction medium was removed and replaced by Medium 199 containing 10\% fetal calf serum supplemented with insulin $(10 \mathrm{mg} / \mathrm{ml})$ alone. This medium was changed every 2 days. Eight days post-differentiation, cells were incubated with or without test hormone. Following incubation, samples were retained and centrifuged at 
$150 \mathrm{~g}$ for $10 \mathrm{~min}$; the supernatant was stored at $-80{ }^{\circ} \mathrm{C}$ for the assay of leptin. Cells were lysed directly on the plate for determination of protein by the Bio-Rad Protein Assay (Cat no. 500-0006) or for RNA extraction (RNAqueous-4 PGR isolation kit; Ambion Inc.), prior to leptin mRNA determination.

\section{Leptin ELISA}

Plasma leptin was determined by an in-house chemiluminescence ELISA, as previously described (Hardie et al. 1996, Crabtree et al. 2000). Chemiluminescence was achieved by the addition of $100 \mu \mathrm{l} /$ well CDP-Star substrate in enhancer solution (Sapphire-II enhancer in DEA buffer; 1:10; Applied Biosystems, Warrington, UK) and quantified in an MLX luminometer (Dynex, Worthing, West Sussex, UK) in terms of relative light units. Recombinant murine leptin standards (NIBSC, South Mimms, Hertfordshire, UK) were run in triplicate and appropriate blanks of culture medium were included. Results were expressed as a percentage of the control after correction for minor differences in protein levels in the wells. Each incubation was carried out in six individual wells.

\section{$\alpha-M S H$ detection}

Plasma $\alpha$-MSH was detected using a commercial kit according to the manufacturer's instructions (Euro-Diagnostica IDS Ltd, Boldon, Tyne and Wear, UK). All samples were run in duplicate. The minimum level of detection of $\alpha-\mathrm{MSH}$ was $3 \mathrm{pM}$ and the intra- and inter-assay coefficients of variation of the assay were 11.8 and $13.0 \%$ respectively. The cross-reactivity with other POMC peptides (adrenocorticotrophic hormone (ACTH) (1-24), ACTH (1-39), $\beta$-MSH and $\gamma$-MSH) was stated to be $<0.002 \%$.

\section{AgRP detection}

Plasma AgRP was detected using a commercial kit according to the manufacturer's instructions (Phoenix Peptide). All samples were run in duplicate. The detection range for AgRP was $1-128 \mathrm{pg} / \mathrm{ml}$. Cross-reactivity with $\mathrm{AgRP}(83-131)-\mathrm{NH}_{2}$ (mouse), $\operatorname{AgRP}(83-132)-\mathrm{NH}_{2}$ (human) and $\mathrm{AgRP}$ form C was $100 \%$. Cross-reactivity with orexin A, orexin B (human), orexin B (rat, mouse), leptin (human), leptin (mouse), $\alpha$-MSH, glucagon-like peptide (GLP)-1(7-37), GLP-2 and neuropeptide Y (human) was $0 \%$.

\section{RT-PCR of MC4R and MC5R}

RNA was extracted using an RNAqueous-4 PCR isolation kit for DNA-free RNA, following the manufacturer's instructions (AMS Biotechnologies, Abingdon, Oxon, UK). Reverse transcription was carried out on $5 \mu \mathrm{g}$ RNA using the Superscript Preamplification System (Gibco BRL, Maidenhead, Berkshire, UK) according to the manufacturer's instructions. The cDNA was amplified by PCR using rodent-specific primers for the MC-R. The quality of each cDNA and mock cDNA was determined by the relative level of amplification of the rodent $\beta$-actin gene $(542 \mathrm{bp}$ product) as previously described (Hoggard et al. 1997). The primers were as follows: MC4R and MC5R were as previously described (Langouche et al. 2001); MC4R (GenBank Accession number U67863), forward 5'-TTTCATGTGTAGTCTG GCT-3' (nucleotides 389-408), reverse 5'-GAA CGCGCGATACTGT GCAAGCT-3' (nucleotides 694-672), product size 305 bp; MC5R (GenBank Accession number L27081), forward 5'-TTCT TTGTGGGCAGCA TAG-3' (nucleotides 469487), reverse 5'-CAGG GCGTAGAAGATGGT GATGTAC-3' (nucleotides 696-672), product size 228 bp. All primers were synthesised by SigmaGenosys Ltd, Cambridge, UK. PCR was performed on a Touchdown thermal cycler (Thermo Hybaid, Ashford, Middlesex, UK) using the following conditions for both sets of MC-R primers, $95{ }^{\circ} \mathrm{C}(10 \mathrm{~min}) 1 \mathrm{cycle}, 95^{\circ} \mathrm{C}(20 \mathrm{~s}), 60{ }^{\circ} \mathrm{C}(20 \mathrm{~s})$, $72^{\circ} \mathrm{C}(30 \mathrm{~s})$ for 35 cycles followed by a final extension of $72{ }^{\circ} \mathrm{C}$ for $7 \mathrm{~min}$. Agarose gel electrophoresis $(2 \%)$ in the presence of ethidium bromide confirmed the presence of a single band of the expected size. To confirm the identity of the amplified products, restriction analysis was carried out on each PCR product using specific restriction enzymes as previously described (Langouche et al. 2001). SsP1 was specific for MC4R cDNA and MboI was specific for MC5R cDNA. All cDNA samples were amplified by $\beta$-actin primers (data not shown), demonstrating the viability of the RNA. 


\section{Real-time quantitative PCR (Taqman system)}

RNA was extracted using an RNAqueous-4 PCR isolation kit for DNA-free RNA, following the manufacturer's instructions (AMS Biotechnologies). RNA was accurately quantified on the Agilent 2100 Bioanalyser (Agilent Technologies, South Queensferry, West Lothian, UK). This also shows the quality of the RNA extracted from the tissues. Only RNA showing no degradation was processed further. Reverse transcription was carried out on $5 \mu \mathrm{g}$ RNA using the Superscript Preamplification System (Gibco BRL) according to the manufacturer's instructions. The cDNA was amplified by PCR using rodent-specific primers for the leptin gene. The primers were as follows: leptin, forward 74 97, 5'-TTGTCACGAGGATCAAT GACATTT3', GenBank U48849; reverse 157-179, GAC AAACTCAGAATGGGGTGAAG-3', GenBank U48849; and FAM-labelled Taqman probe, 99-121, ACACACGCAGTGGGTATCGGCGA, Genbank U48849.

The cDNAs were also amplified using rodent ribosomal 18S RNA and glyceraldehyde 3phosphate dehydrogenase (GAPDH) control primers (PE Applied Biosystems, Inc., Foster City, CA, USA), following the manufacturer's instructions. PCR was performed on an Applied Biosystems ABI Prism 7700 sequence detection system under the following conditions; $50{ }^{\circ} \mathrm{C}(2 \mathrm{~min})$ for 1 cycle, $95^{\circ} \mathrm{C}(10 \mathrm{~min}) 1$ cycle, $95{ }^{\circ} \mathrm{C}(15 \mathrm{~s}), 60{ }^{\circ} \mathrm{C}$ (1 min) for 40 cycles. All samples were run in triplicate and were all within the standard curve. Values were standardised to both $18 \mathrm{~S}$ and GAPDH and expressed as a percentage of the control.

\section{Statistics}

Between-group comparisons were made using unpaired Student's $t$-tests. Results were considered statistically significant if the $P$ value was less than $0 \cdot 05$.

\section{Results}

\section{Regulation of leptin secretion and expression in primary culture of differentiated rat adipocytes in vitro}

The rat adipocytes were treated at day 8 post-differentiation. Twenty-four hours later the culture medium was harvested for the measure-

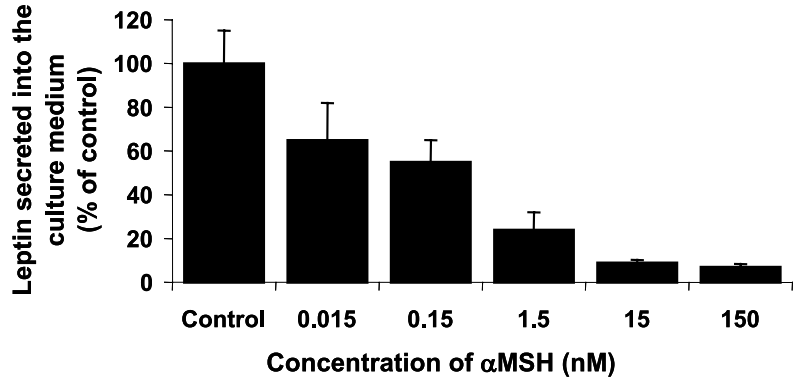

Figure 1 Addition of $\alpha-\mathrm{MSH}$ at various concentrations as shown to primary cultures of differentiated adipocytes for $24 \mathrm{~h}$ inhibits leptin protein secretion into the culture medium compared with untreated culture as determined by a leptin-specific ELISA. $\mathrm{EC}_{50}=0.24 \mathrm{nM} . n=6$ for each point, per cent of control \pm S.E.M.

ment of leptin, using a sensitive chemiluminescent ELISA and cells extracted for protein determination.

Effect of a-MSH on leptin secretion into the culture medium

Differentiated rat adipocytes were incubated for $24 \mathrm{~h}$ with five different concentrations of $\alpha-\mathrm{MSH}$ $(0 \cdot 015,0 \cdot 15,1 \cdot 5,15$ and $150 \mathrm{nM})$ and compared with control cells (Fig. 1). Addition of $\alpha-\mathrm{MSH}$ resulted in a dose-dependent decrease in leptin secretion into the culture medium. The $\mathrm{EG}_{50}$ for the reduction of leptin secretion by $\alpha-\mathrm{MSH}$ was determined to be approximately $0 \cdot 24 \mathrm{nM}$ (Fig. 1). This experiment was repeated several times with similar results.

Effect of a potent a-MSH analogue and a-MSH antagonists on leptin secretion into the culture medium

The effect of $\left[\mathrm{Nle}^{4}, \mathrm{D}-\mathrm{Phe}^{7}\right]-\alpha-\mathrm{MSH}$, a potent analogue of $\alpha$-MSH, on leptin secretion into the medium was determined on differentiated primary adipocytes (Fig. 2). Cells were incubated with $\left[\mathrm{Nle}^{4}, \mathrm{D}-\mathrm{Phe}{ }^{7}\right]-\alpha-\mathrm{MSH}$ for $24 \mathrm{~h}$ and compared with control (medium only). [Nle $\left.{ }^{4} \mathrm{D}-\mathrm{Phe}^{7}\right]-\alpha-\mathrm{MSH}$ at $15 \mathrm{nM}$ decreased leptin secretion into the culture medium compared with the control adipocytes $(P<0 \cdot 05)$. This decrease in leptin secretion by $\left[\mathrm{Nle}^{4}, \mathrm{D}-\mathrm{Phe}{ }^{7}\right]-\alpha-\mathrm{MSH}$ was inhibited by the addition of SHU9119 $(1 \mu \mathrm{M})$ or AgRP $(200 \mathrm{nM})$. Pre-incubation with the antagonists prior to the addition of $\alpha-\mathrm{MSH}$ had the same effect on leptin secretion (data not shown). The addition of AgRP 


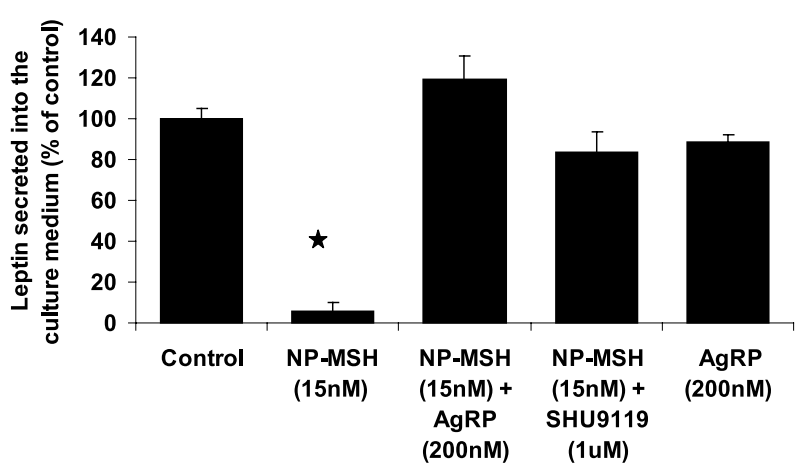

Figure 2 Addition of the potent $\alpha-\mathrm{MSH}$ analogue $\left[\mathrm{Nle}^{4}, \mathrm{~d}-\mathrm{Phe}^{7}\right]-\alpha-\mathrm{MSH}$ (NP-MSH) at $15 \mathrm{nM}$ to primary cultures of differentiated adipocytes for $24 \mathrm{~h}$ significantly $(P<0.05)$ inhibits leptin protein secreted into the cell culture medium compared with untreated control cells, as determined by a leptin-specific ELISA. This inhibition of leptin by $\left[\mathrm{Nle}^{4}, \mathrm{D}-\mathrm{Phe}^{7}\right]-\alpha-\mathrm{MSH}$ is blocked by the addition of SHU9119 $(1 \mu \mathrm{M})$ or AgRP (200 nM), which are both potent antagonists of $\alpha-\mathrm{MSH}$. AgRP (200 nM) treatment of the cells on its own has no effect on leptin secretion into the culture media. $n=6$ for each point, per cent of control \pm S.E.M. ${ }^{*} P<0.05$.

(200 $\mathrm{nM}$ ) in the absence of $\alpha$-MSH had no effect on the secretion of leptin. Similar results were obtained in two further separate experiments.

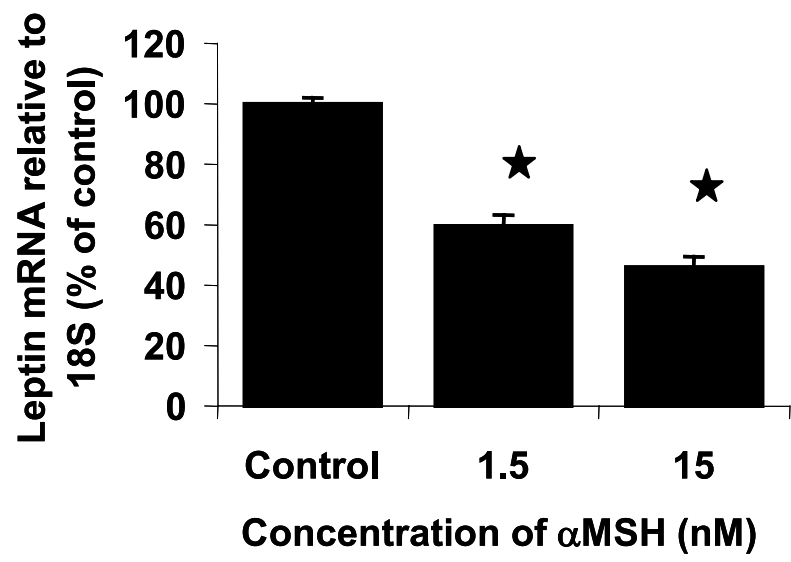

Figure 3 The addition of $\alpha-\mathrm{MSH}(1.5$ or $15 \mathrm{nM}$ ) to differentiated primary cultures of rat adipocytes for $6 \mathrm{~h}$ significantly $\left({ }^{\star} P<0.05\right)$ decreased leptin mRNA expression, when compared with the untreated control cells. Leptin mRNA was determined by real-time quantitative PCR using the Taqman assay and primers specific for leptin. Results are expressed as a percentage of the control, $n=3$ for each point \pm S.E.M, related to the expression of the house keeping gene $18 \mathrm{~S}$. $\mathbf{a}$

\section{P A Br P CoBmCoM}
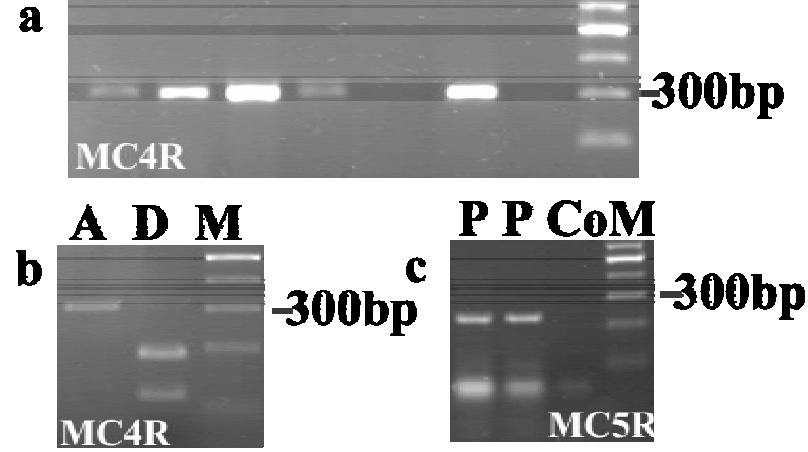

Figure 4 RT-PCR ethidium bromide-stained gels showing the expression of MC4R ( $a$ and $b$ ) and MC5R (C) in primary cultures of rat differentiated adipocytes $(\mathrm{P})$, rat adipose $(\mathrm{A})$ tissue (epididymal), rat brain $(\mathrm{Br})$, control PCR (Co), mouse brain, (Bm), MC4R band amplified from adipose tissue digested with SsP1 (D), and $100 \mathrm{bp}$ ladder with the $300 \mathrm{bp}$ fragment shown.

\section{Effect of $a-M S H$ on leptin mRNA expression}

The addition of $\alpha$-MSH $(1.5$ or $15 \mathrm{nM})$ to differentiated primary cultures of rat adipocytes for 6 h significantly $(P<0 \cdot 05)$ decreased leptin mRNA expression, as determined by the Taqman assay using primers specific for leptin mRNA (Fig. 3). $\alpha$-MSH $(1.5 \mathrm{nM})$ decreased leptin mRNA by approximately $40 \%$ when compared with the control cells (medium only).

\section{MC-R subtypes present in differentiated primary cultures of rat adipocytes and rat adipose tissue}

To determine if MC4R receptors are present in the primary cultures of rat adipocytes and in rat adipose tissue we used RT-PGR and primers specific to MC4R (Fig. 4a and b) or to MC5R as a control (Fig. 4c). Rat and mouse brain were used as control tissue for MC4R. Half of the MC4R PCR reaction was analysed on an ethidium bromidestained agarose gel and the other half was digested with $\mathrm{SsPl}$ restriction enzyme, which yields two PCR fragments of 119 and $186 \mathrm{bp}$, to confirm the identity of the product (Fig. 4b). Analysis shows that MC4R and MC5R are present in rat adipose tissue and in differentiated primary cultures of rat adipocytes.

Specificity of MC-R mRNA amplification was demonstrated. No $\beta$-actin band was amplified from the mock cDNA, indicating that the DNAse 


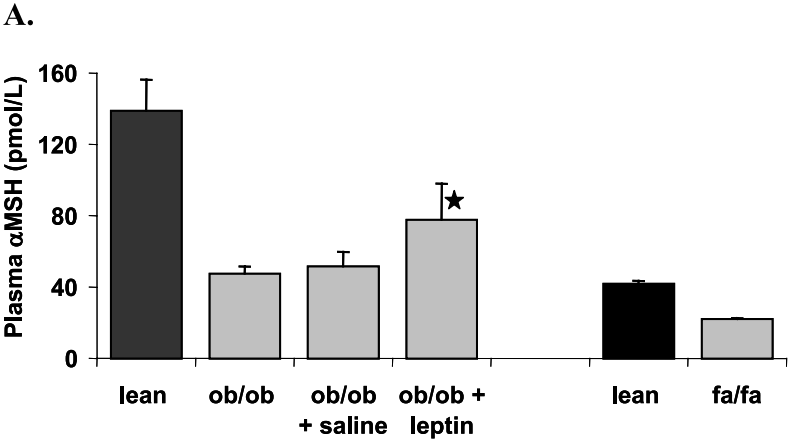

B.

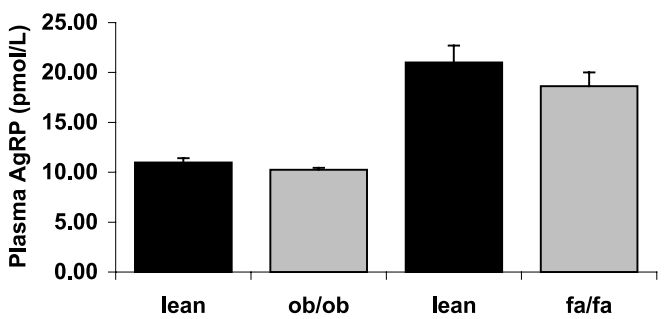

Figure 5 Circulating $\alpha-\mathrm{MSH}(\mathrm{A})$ and $\mathrm{AgRP}(\mathrm{B})$ in: lean (+/?) and ob/ob Aston mice; lean (+/?) and fa/fa Zucker rats and in ob/ob mice following the administration of leptin or control saline i.p. $\alpha-\mathrm{MSH}$ is significantly lower in leptin-deficient $o b / o b$ mice (average weight $73 \mathrm{~g} ;{ }^{\star} P<0.05$ ), and leptin receptordefective fa/fa rats (average weight $350 \mathrm{~g} ; P<0.05$ ) compared with their respective lean littermates $(+/$ ?) (average weights 37 and $270 \mathrm{~g}$ respectively). $n=8 \pm$ S.E.M. The administration of leptin i.p. at $1.7 \mathrm{mg} / \mathrm{kg}$ body weight to ob/ob mice increases circulating $\alpha-\mathrm{MSH}$ compared with saline-treated controls after $1 \mathrm{~h}(\mathrm{~A})$. In contrast no significant changes in plasma AgRP were observed in either ob/ob mice or fa/fa rats compared with their respective lean littermates (B). $n=6 \pm$ S.E.M.

treatment in the RNA extraction was complete and that any bands amplified from the RT-RNA were not as a result of contaminating DNA present in the preparation.

\section{Circulating levels of $\alpha-\mathrm{MSH}$ and AgRP in $o b / o b$ mice and $\mathrm{fa} / \mathrm{fa}$ rats}

To investigate whether leptin regulates the release of $\alpha-\mathrm{MSH}$ or AgRP into the circulation we examined plasma levels of $\alpha-\mathrm{MSH}$ and AgRP in leptin-deficient $o b / o b$ mice and leptin receptordefective $f a / f a$ rats, comparing the levels of these hormones with their lean littermates (Fig. 5A). Circulating $\alpha$-MSH was significantly $(P<0.05)$ lower in leptin-deficient $a b / o b$ mice, and leptin

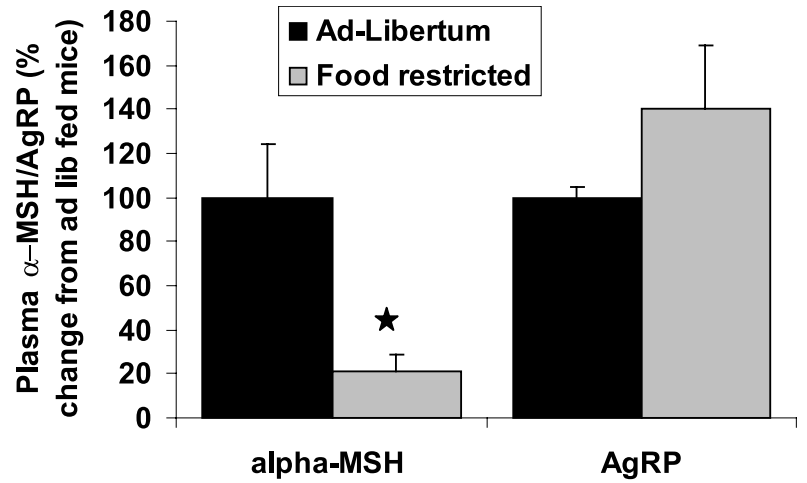

Figure 6 Effect of food deprivation on plasma concentrations of $\alpha-\mathrm{MSH}$ and AgRP in lean (+/?) Aston mice. In mice that were fasted for $24 \mathrm{~h}$ with no restrictions to water access, plasma $\alpha-\mathrm{MSH}$ is significantly decreased $P<0.05$ compared with the freely fed controls. An increase in AgRP was observed but this was not significant over $24 \mathrm{~h}$. Results, $n=9$, are expressed as a percentage of the control non-foodrestricted animals. Average body weight loss was $0.19 \mathrm{~g}$ in the control group compared with $4.61 \mathrm{~g}$ in the fasted rodents.

receptor-defective $f a / f a$ rats $(P<0.05)$ compared with their respective lean littermates $(+/$ ?). The administration of leptin i.p. at $1.7 \mathrm{mg} / \mathrm{kg}$ body weight to $o b / o b$ mice increased circulating $\alpha-\mathrm{MSH}$ by approximately $1 \cdot 5$-fold compared with salinetreated controls after $1 \mathrm{~h}(P<0 \cdot 05)$ (Fig. 5A). No significant changes in AgRP were observed in either $o b / o b$ mice or $f a / f a$ rats compared with their respective lean littermates (Fig. 5B).

\section{Circulating levels of $\alpha-M S H$ and AgRP in $24 \mathrm{~h}$ food-deprived mice}

To investigate whether $\alpha-\mathrm{MSH}$ or AgRP have a role in the regulation of food intake, plasma levels of these hormones were determined in $24 \mathrm{~h}$ food-deprived mice (Fig. 6). Plasma $\alpha$-MSH levels were significantly lower $(P<0 \cdot 05)$ compared with the freely fed controls. There was no significant change in circulating AgRP, although there was a trend for AgRP levels to be higher in the food-deprived group.

\section{Discussion}

We have shown that expression of leptin, both mRNA and protein, is inhibited in vitro by the 
administration of $\alpha$-MSH to primary cultures of rat adipocytes, and that this effect is antagonised by MC4/3R antagonists. This inhibition of leptin by $\alpha$-MSH in rat adipocytes $\left(\mathrm{EC}_{50}=0.24 \mathrm{nM}\right)$ is much more pronounced that that previously reported in murine 3T3-L1 cells $\left(\mathrm{EC}_{50}=36 \mathrm{nM}\right)$. This may be due to the presence of the MC4R in rat adipocytes, a receptor subtype that is also present in human adipose tissue, but which is absent in 3T3-L1 cells. Leptin administered to $o b / o b$ mice in turn increases the release of $\alpha-\mathrm{MSH}$ into the circulation, suggesting a possible feedback loop in vivo whereby increased leptin secretion from adipose tissue stimulates an increase in plasma $\alpha-\mathrm{MSH}$, which in turn inhibits leptin release. However, we propose that the physiological role of this putative homeostatic feedback varies with the state of energy balance, since in the fasting state low plasma $\alpha-\mathrm{MSH}$ and low plasma leptin are co-incident.

At this stage it is not possible to say whether this inhibition of leptin expression is a direct effect on gene transcription or the result of the potent lipolytic action of $\alpha$-MSH on adipose tissue (Forbes et al. 2001), as a reduction in cell size has been shown to be an important regulator of leptin expression from adipose tissue (Van Harmelen et al. 1998). However, in support of a direct effect, MC-Rs are coupled to adenylyl cyclases, and cAMP has been shown to strongly down regulate leptin mRNA expression in rat adipocytes in culture (Slieker et al. 1996).

Signalling in the POMC system involves five separate receptors, which respond to the different peptides in the system, but with a measure of cross-talk between them (Wikberg et al. 2000). A number of MC-Rs have been identified in adipose tissue, but there appear to be clear differences between species. In human adipose tissue, MC1R, MC2R, MC4R and MC5R have been shown to be expressed (Chagnon et al. 1997), which contrasts with murine adipose tissue where only the MC2R and MC5R have been reported (Boston \& Cone 1996). $\alpha$-MSH is unlikely to signal through MC2R, which is the ACTH receptor (Wikberg et al. 2000). Consequently, it has previously been suggested that in 3T3-L1 murine adipocytes $\alpha-\mathrm{MSH}$, and in addition ACTH, down regulate leptin expression via the MC5R (Norman et al. 2003). The presence of MC4R in rat adipocytes, but not murine 3T3-L1 cells, may contribute to the much lower $\mathrm{EG}_{50}$ value of $0.24 \mathrm{nM}$ reported here for the action of $\alpha$-MSH on rat primary cultures of adipocytes compared with $36 \mathrm{nM}$ for the action of $\alpha$-MSH on leptin in 3T3-L1 cells. In support of $\alpha$-MSH acting through the MC4R in rat adipocytes, both AgRP (200 nM) and SHU9119 $(1 \mu \mathrm{M})$ block the inhibition of leptin secretion by $\alpha-\mathrm{MSH}$, consistent with their potent antagonism of $\alpha-\mathrm{MSH}$ action at the MC3R and MC4R (Wikberg et al. 2000). The presence of the $\mathrm{MC} 4 \mathrm{R}$ in rat adipose tissue may mean that this is a better model of human adipose tissue than mouse cells, since human adipocytes also express this receptor. Regardless of the receptor that $\alpha-\mathrm{MSH}$ is signalling through, it clearly has an important signalling role in the regulation of leptin expression, at least in rodents and probably in humans too.

Agouti $(100 \mathrm{nM})$, which acts in a similar manner to AgRP, has been shown to increase (approximately $1 \cdot 6$-fold) both leptin secretion and mRNA expression in differentiated 3T3-L1 murine adipocytes (Mynatt \& Stephens 2001). We therefore examined whether AgRP had a direct effect on leptin expression in primary culture of rat adipocytes. The addition of AgRP at supraphysiological levels to our primary culture of rat adipocytes appeared to have no direct effect on leptin secretion. This again may reflect a difference between rat and mouse, such as in the type of receptor present.

We investigated whether leptin regulates the release of $\alpha-\mathrm{MSH}$ or $\mathrm{AgRP}$ into the circulation. Consistent with this proposal, plasma $\alpha-\mathrm{MSH}$ was decreased in both the leptin-deficient $o b / o b$ mouse and the leptin receptor-defective $f a / f a$ rat compared with their respective lean littermates. Further, administration of leptin to $a b / o b$ mice stimulated an increase in circulating plasma $\alpha$-MSH. Previous studies have shown similar effects (Forbes et al. 2001). This suggests some form of feedback loop between the peripheral secretion of leptin from adipose tissue and the release of $\alpha$-MSH into the plasma. In keeping with this, POMG gene expression is decreased in the hypothalamus of the $o b / o b$ mouse (Thornton et al. 1997). This is consistent with the hypothalamus being the source of plasma $\alpha$-MSH. In contrast we observed no change in plasma AgRP in either the $o b / o b$ mouse or the $f a / f a$ rat compared with their respective lean littermates, suggesting that the release of $\mathrm{AgRP}$ into the circulation is not regulated by plasma leptin. This is in contrast to the 
expression of $\mathrm{AgRP}$ in the arcuate nucleus of the hypothalamus, which has been shown to be regulated by leptin, suggesting that the hypothalamus may not be the source of circulating AgRP (Shutter et al. 1997). In humans and rodents the most abundant site of AgRP mRNA expression is the hypothalamus, followed by the adrenal glands (cortex and medulla). AgRP expression has also been reported in lung, kidney, testis, ovary and muscle tissues (Shutter et al. 1997, Takeuchi et al. 2000).

To investigate this putative feedback loop further we looked at the plasma levels of both $\alpha-\mathrm{MSH}$ and AgRP in $24 \mathrm{~h}$ food-deprived mice. It would appear from these studies that the physiological significance of this feedback loop probably depends upon the underlying state of energy balance, since in the fasting state low plasma $\alpha-\mathrm{MSH}$ is paralleled by low plasma leptin. A possible explanation is that in fasting the sympathetic system, which we have previously shown to be a key inhibitor of leptin (Trayhurn et al. 1998), overrides the $\alpha-\mathrm{MSH}$ signal, maintaining a low plasma leptin level, which in turn results in a low plasma $\alpha-\mathrm{MSH}$. In addition the $\alpha$-MSH signal may be further inhibited by the increase in AgRP observed in the fasting state ( $\mathrm{Li}$ et al. 2000); although there was no significant change in circulating AgRP in response to a $24 \mathrm{~h}$ fast, the trend apparent in our data was in agreement with a previous report in $48 \mathrm{~h}$ food-deprived mice (Li et al. 2000). The physiological role of AgRP on adipose tissue MC4R may be questioned as the concentrations of AgRP shown in this study and in previous work are less than the $K_{\mathrm{i}}$ $(2.5 \mathrm{nM})$ for AgRP at this receptor (Yang et al. 1999). However, circulating levels in vivo may not correlate with in vitro estimations of concentrations necessary to inhibit these receptors, particularly in view of the postulated role of syndecan- 3 to bind and potentiate the effects of $\mathrm{AgRP}$ at MC-Rs in the hypothalamus (Reizes et al. 2001).

It should, however, be noted that the plasma levels of $\alpha$-MSH reported here in the mouse, although within the physiological range for the regulation of lipolysis in vitro (Kastin et al. 1975), are lower than the previously reported $\mathrm{EG}_{50}$ value for the induction of leptin in murine 3T3 cells (Norman et al. 2003). The inhibition of leptin by basal levels of circulating $\alpha$-MSH under physiological conditions in the mouse therefore requires further clarification.
Both plasma $\alpha$-MSH (Katsuki et al. 2000) and AgRP (Katsuki et al. 2001) are increased in obese humans compared with lean subjects, suggesting that these circulating hormones may be involved in the regulation of food intake/body fat independently of any central effects, a hypothesis we have investigated further in rodents. We have shown that $\alpha$-MSH regulates leptin expression in vitro, an effect which is antagonised by AgRP. This appears to form part of an integrative regulatory loop with central regulation of POMC gene expression, and subsequent release of $\alpha-\mathrm{MSH}$ into the circulation. This putative feedback loop is a construct based on available evidence, but its regulatory capability in the normal, leptin-competent rodent under normal physiological conditions remains to be determined. In negative energy balance we suggest that the $\alpha$-MSH signal is overridden by the sympathetic control of leptin production and lipolysis, reinforced by the antagonism of the $\alpha-\mathrm{MSH}$ signal as a result of an increase in plasma AgRP.

\section{Acknowledgements}

This work was supported by a grant from the Scottish Executive Environment and Rural Affairs Department (SEERAD).

\section{References}

Ahima RS, Saper CB, Flier JS \& Elmquist JK 2000 Leptin regulation of neuroendocrine systems. Frontiers in Neuroendocrinology $21263-307$.

Boston BA \& Cone RD 1996 Characterization of melanocortin receptor subtype expression in murine adipose tissues and in the 3T3-L1 cell line. Endocrinology 137 2043-2050.

Chagnon YC, Chen WJ, Perusse L, Chagnon M, Nadeau A, Wilkison WO \& Bouchard C 1997 Linkage and association studies between the melanocortin receptors 4 and 5 genes and obesity-related phenotypes in the Quebec Family Study. Molecular Medicine 3 663-673.

Crabtree JT, Duncan JS \& Trayhurn P 2000 A highly sensitive chemiluminescence ELISA for the measurement of leptin. International fournal of Obesity $\mathbf{2 4} 136$.

Forbes S, Bui S, Robinson BR, Hochgeschwender U \& Brennan MB 2001 Integrated control of appetite and fat metabolism by the leptin-proopiomelanocortin pathway. PNAS 98 4233-4237.

Hardie LJ, Rayner DV, Holmes S \& Trayhurn P 1996 Circulating leptin levels are modulated by fasting, cold-exposure and insulin administration in lean but not Zucker $(\mathrm{Fa} / \mathrm{Fa})$ rats as measured by ELISA. Biochemical and Biophysical Research Communications 223 660-665.

Hoggard N, Mercer JG, Rayner DV, Moar K, Trayhurn P \& Williams LM 1997 Localization of leptin receptor mRNA splice variants in murine peripheral tissues by RT-PCR and in situ hybridization. Biochemical and Biophysical Research Communications 232 383-387. 
Hoggard N, Duncan J, Hunter L, Crabtree J \& Rayner DV 2001 Circulating alpha-MSH directly down regulates adipocyte expression of leptin. International Fournal of Obesity 25 S39.

Jo SK, Yun SY, Chang KH, Cha DR, Cho WY, Kim HK \& Won NH 2001 Alpha-MSH decreases apoptosis in ischaemic acute renal failure in rats: possible mechanism of this beneficial effect. Nephrology, Dialysis, Transplantation 16 1583-1591.

Kastin AJ, Redding TW, Hall R, Besser GM \& Schally AV 1975 Lipid mobilizing hormones of the hypothalamus and pituitary. Pharmacology, Biochemistry, and Behaviour 3 121-126.

Katsuki A, Sumida Y, Murashima S, Furuta M, Araki-Sasaki R, Tsuchihashi K, Hori Y, Yano Y \& Adachi Y 2000 Elevated plasma levels of alpha-melanocyte stimulating hormone (alpha$\mathrm{MSH}$ ) are correlated with insulin resistance in obese men. International Fournal of Obesity 24 1260-1264.

Katsuki A, Sumida Y, Gabazza EC, Murashima S, Tanaka T, Furuta M, Araki-Sasaki R, Hori Y, Nakatani K, Yano Y et al. 2001 Plasma levels of agouti-related protein are increased in obese men. Journal of Clinical Endocrinology and Metabolism 86 1921-1924.

Langouche L, Roudbaraki M, Pals K \& Denef C 2001 Stimulation of intracellular free calcium in GH3 cells by gamma3-melanocytestimulating hormone. Involvement of a novel melanocortin receptor? Endocrinology 142 257-266.

Li JY, Finniss S, Yang YK, Zeng Q Qu SY, Barsh G, Dickinson C \& Gantz I 2000 Agouti-related protein-like immunoreactivity: characterization of release from hypothalamic tissue and presence in serum. Endocrinology 141 1942-1950.

MacNeil DJ, Howard AD, Guan X, Fong TM, Nargund RP, Bednarek MA, Goulet MT, Weinberg DH, Strack AM, Marsh DJ et al. 2002 The role of melanocortins in body weight regulation: opportunities for the treatment of obesity. European Fournal of Pharmacology 440 141-157.

Mitchell SE, Rees WD, Hardie LJ, Hoggard N, Tadayyon M, Arch JRS \& Trayhurn P 1997 ob gene expression and secretion of leptin following differentiation of rat preadipocytes to adipocytes in primary culture. Biochemical and Biophysical Research Communications 230 360-364.

Mynatt RL \& Stephens JM 2001 Agouti regulates adipocyte transcription factors. American Fournal of Physiology. Cell Physiology 280 C954-C961.

Norman D, Isidori AM, Frajese V, Caprio M, Chew SL, Grossman AB, Clark AJ, Michael Besser G \& Fabbri A 2003 ACTH and alpha-MSH inhibit leptin expression and secretion in 3T3-L1 adipocytes: model for a central-peripheral melanocortin-leptin pathway. Molecular and Cellular Endocrinology 200 99-109.

Rajora N, Boccoli G, Burns D, Sharma S, Catania AP \& Lipton JM 1997 Alpha-MSH modulates local and circulating tumor necrosis factor-alpha in experimental brain inflammation. Fournal of Neuroscience 17 2181-2186.

Reizes O, Lincecum J, Wang Z, Goldberger O, Huang L, Kaksonen M, Ahima R, Hinkes MT, Barsh GS, Rauvala H et al. 2001 Transgenic expression of syndecan- 1 uncovers a physiological control of feeding behavior by syndecan-3. Cell $\mathbf{1 0 6}$ 105-116.

Shimizu H, Tanaka Y, Sato N \& Mori M 1995 Alpha-melanocyte-stimulating hormone (MSH) inhibits insulin secretion in HIT-T 15 cells. Peptides 16 605-608.

Shutter JR, Graham M, Kinsey AC, Scully S, Luthy R \& Stark KL 1997 Hypothalamic expression of ART, a novel gene related to agouti, is up-regulated in obese and diabetic mutant mice. Genes and Development 11 593-602.

Slieker LJ, Sloop KW, Surface PL, Kriauciunas A, LaQuier F, Manetta J, Bue-Valleskey J \& Stephens TW 1996 Regulation of expression of ob mRNA and protein by glucocorticoids and cAMP. Fournal of Biological Chemistry 271 5301-5304.

Takeuchi S, Teshigawara K \& Takahashi S 2000 Widespread expression of Agouti-related protein (AGRP) in the chicken: a possible involvement of AGRP in regulating peripheral melanocortin systems in the chicken. Biochimica et Biophysica ActaMolecular Cell Research 1496 261-269.

Thornton JE, Cheung CC, Clifton DK \& Steiner RA 1997 Regulation of hypothalamic proopiomelanocortin mRNA by leptin in ob/ob mice. Endocrinology 138 5063-5066.

Trayhurn P, Duncan JS, Hoggard N \& Rayner DV 1998 Regulation of leptin production: a dominant role for the sympathetic nervous system? Proceedings of the Nutrition Society 57 413-419.

Van Harmelen V, Reynisdottir S, Eriksson P, Thorne A, Hoffstedt J, Lonnqvist F \& Arner P 1998 Leptin secretion from subcutaneous and visceral adipose tissue in women. Diabetes 47 913-917.

Vinson GP, Whitehouse BJ, Dell A, Bateman A \& McAuley ME 1983 alpha-MSH and zona glomerulosa function in the rat. Fournal of Steroid Biochemistry 19 537-544.

Wikberg JE, Muceniece R, Mandrika I, Prusis P, Lindblom J, Post C \& Skottner A 2000 New aspects on the melanocortins and their receptors. Pharmacological Research 42 393-420.

Yang YK, Thompson DA, Dickinson CJ, Wilken J, Barsh GS, Kent SB \& Gantz I 1999 Characterization of Agouti-related protein binding to melanocurtin receptors. Molecular Endocrinology 13 $148-155$.

Zimanyi IA \& Pelleymounter MA 2003 The role of melanocortin peptides and receptors in regulation of energy balance. Current Pharmaceutical Design 9 627-641.

\section{Received 6 August 2003} Accepted 20 October 2003 